\title{
Liver histopathological changes in Clarias gariepinus exposed to ethanol extract of Adenium obesum stem bark
}

\author{
ABALAKA, S. E. ${ }^{1 *}$, FATIHU, M. Y. ${ }^{1}$, IBRAHIM, N. D. G. ${ }^{1}$ and AMBALI, S. F. ${ }^{2}$ \\ ${ }^{1}$ Department of Veterinary Pathology, Ahmadu Bello University, 930214, Zaria, Nigeria \\ ${ }^{2}$ Department of Veterinary Pharmacology and Toxicology, Ahmadu Bello University, 930214, Zaria, Nigeria \\ *E-mail: seabalaka@yahoo.co.uk
}

\begin{abstract}
Introduction: Histopathological effects of ethanol extract of Adenium obesum stem bark on the liver of Clarias gariepinus was investigated over a 96-h exposure period as an effective organic piscicide. Materials and Methods: An acute static toxicity bioassay was performed after a preliminary concentration range finding test was conducted. Results: Exposed fish showed adaptation behavioural changes with those of respiratory distress and abnormal nervous signs of toxicity, which was concentration-dependent. Mortality was recorded in some of the exposed fish while a median lethal concentration of $7.15 \mathrm{mgL}^{-1}$ was established for the extract in the exposed fish. Non-significant $(\mathrm{p}>0.05)$ changes were recorded in serum aspartate aminotransferase, alanine aminotransferase and alkaline phosphatase activities of the exposed fish. Moderate liver damage was observed in the exposed fish based on the degree of tissue change (DTC) grading where significant $(\mathrm{p}<0.05)$ differences were observed between the DTC of the exposed groups and the control. Conclusion: Ethanol extract of $A$. obesum stem bark was toxic to the exposed fish with evidence of hepatotoxicity and therefore, can be used to eradicate the hardy C.gariepinus from aquatic environments.
\end{abstract}

Keywords: Adenium obesum, Clarias gariepinus, hepatotoxicity, serum enzymes, histopathology.

\section{Introduction}

Although Clarias gariepinus is indigenous to Africa (BRUTON, 1976; PICKER and GRIFFITHS, 2001) it is absent from the Maghreb, Upper and Lower Guinea and Cape provinces (FOOD..., 2011). However, the fish has been introduced into Europe, Asia and South America in recent times (FOOD..., 1992). Clarias gariepinus is reportedly a widespread invasive fish species, which is suspected to be a major threat to native fish fauna (CASAL, 2006; SILVA, NGUYEN, TURCHINI et al., 2009) in addition to being a weed fish in earthen ponds prior to the stocking of desired fish stock. This is due to its ability to adapt to diverse environments even with poor water quality due to its accessory breathing organs (HETCH, OELLERMAN and VERHEUST, 1996) along with its high fecundity, flexible phenomenon, wide habitat preferences and environmental tolerance as well as their ability to feed on a wide range of prey (BRUTON, 1986).

There is therefore, a need to eradicate these hardy air-breathing fish from new habitats or earthen fishponds before re-stocking in order to safeguard native fish species or desired fish stock in earthen aquatic ponds. This is an important step in effective aquatic pond management as the former compete and/or prey on the later in addition to being able to surviving in moist burrows and mud even when such earthen ponds are drained (AYOTUNDE, OFFEM and BEKEH, 2011). Although air-breathing fish are normally resistant to toxicants (KULAKKATTOLICKAL and KRAMER, 1988), the use of synthetic chemicals to eradicate them from aquatic environments is well documented (TERAZAKI, THARNBUPPA and NAKAYAMA, 1980; GRIBGRATOK, 1981; MARKING, 1992). However, these synthetic chemicals are known to cause environmental pollution (MONDAL, BARAT and MUKHOPADHYAY, 2007) due to their harmful residues in aquatic environments (KOESOMADINATA, 1980; CAGAUAN and ARCE, 1992). Emphasis has now shifted globally towards the use of plants that are poisonous to fish or piscicidal plants instead as effective alternatives (SINGH, SINGH, MISRA et al., 1996; FAFIOYE, 2005) where such practices have also been documented (MURPHY and WILLIS, 1996; LINTERMANS, 2000, VAN ANDEL, 2000; CAGAUAN, GALAITES and FAJARDO, 2004). This is because piscicidal plants are more environmentally friendly in terms of easy bio-degradation with little or no residues in the environment (STALIN, KIRUBA and DAS, 2008).

Adenium obesum is a typical piscicidal plant (ADAMU, ABAYEH, AGHO et al., 2005; OYEN, 2008). Although the plant is indigenous to the Sahel region of Africa, Central Africa and the Arabia peninsula (PLAIZIER, 1980; ARBONNIER, 2004), it is also found worldwide where they are usually cultivated for ornamental purposes (OMINO and KOKWARO 1993; HASTUTI, SURANTO and SETYONO, 2009). This is due to its characteristic "showy" flowers (ZORLONI 2000). The piscicidal activity $A$. obesum is known globally (ADAMU, ABAYEH, AGHO et al., 2005; OYEN, 2008; BADWENDAVIS, 2010). However, there is paucity of information on histopathological effects of the plant on some organs of exposed fish thereby necessitating the work. Therefore, the study evaluates histopathological changes in the liver of African catfish, C.gariepinus exposed to ethanol extract of Adenium obesum stem bark. 


\section{Materials and Methods}

\subsection{Plant extraction}

Adenium obesum were collected from the open fields of Rurum town, Rano Local Government Area, Kano State, Nigeria between the Months of January - April, 2011. Mallam Musa Mohammed authenticated the plant at the Herbarium, Department of Biological Sciences, Ahmadu Bello University (A. B. U.), Zaria, Nigeria where a specimen was already deposited (Voucher No. 1386). The barks were sun-dried and pounded into powder after removing them from the stems. A total of $3.95 \mathrm{~kg}$ of the powder was macerated in $21 \mathrm{~L}$ of ethanol $(96.0 \%$ vol. Sigma-Aldrich ${ }^{\circledR}$ Inc., St. Louis, MO 63178, USA) for 3 days (72-hour) in a separation funnel whose mouth was plugged with cotton wool. The extract was concentrated to dryness in an evaporation dish at room temperature until constant weights were obtained (ABU-DAHAB and AFIFI, 2007).

\subsection{Fish toxicity bioassay}

Adult Clarias gariepinuswere purchased from a commercial catfish farm (Fannasson Investments Limited, Kano, Nigeria) and authenticated at the Fishery Section, Department of Biological Sciences, A. B. U., Zaria, Nigeria. Experimental fish were acclimatizated under natural day and night photo-periods (12/12-hour) for 21 days in a rectangular plastic pond $(1.54 \times 1.05 \times 0.75 \mathrm{~m})$ whose water was changed completely once in every three days. Fish were fed to ad libitum twice daily with $6 \mathrm{~mm}$ Coppens ${ }^{\circledR}$ fish feed for aquaculture (Coppens ${ }^{\circledR}$ International bv., 5700 AM Helmond, Holland). During the acclimatization period, experimental fish were observed for disease conditions and mortality (ORGANIZATION..., 1992). Feeding was stopped 24-h prior to and during the 96-h exposure period in order to prevent interference with stomach contents and wastes in the fish culture water (SMITH, SHAW and HANDY, 2007; OLUFAYO, 2009) Signs of toxicity were monitored and promptly recorded.

Fish toxicity bioassay involved the exposure of 126 adult Clarias gariepinus of $265.50 \pm 4.03 \mathrm{~g}$ mean weight and $32.85 \pm 0.16 \mathrm{~cm}$ mean total length to $6.25 \mathrm{mgL}^{-1}, 7.50 \mathrm{mgL}^{-1}$, $8.20 \mathrm{mgL}^{-1}, 8.80 \mathrm{mgL}^{-1}$ and $9.30 \mathrm{mgL}^{-1}$ of the extract and a control based on the Organization... (1992) in triplicates over a 96-h exposure period to determine the median lethal concentration $\left(\mathrm{LC}_{50}\right)$ using the Probit and logit method (FINNEY, 1971). This was after performing a preliminary concentration range finding test to determine the five different extract concentrations used along with the control as described by Fafioye (2001).

\subsection{Biochemical analyses}

At the end of the 96-h exposure period, seven surviving fish per exposure group were randomly selected for blood sampling. However, only the surviving six, five and three fish from the groups exposed to $8.20 \mathrm{mgL}^{-1}, 8.80 \mathrm{mgL}^{-1}$ and $9.30 \mathrm{mgL}^{-1}$ of the extract were sampled. Blood were collected via caudal vene-puncture as described by Kori-Siakpere, Ake and Idoge (2005) and dispensed into sample bottles without any anticoagulant for biochemical analyses. These were allowed to clot and centrifuged at $1,006 \mathrm{~g}$ for 10 minutes to obtain the serum. Aspartate aminotransferase (AST) and alanine aminotransferase (ALT) activities were determined using the Reference method by International Federation of Clinical
Chemistry (SCHWARTZ, CEDIEL, CURNOW et al., 1985) using an auto-analyzer (Bayer Express Plus, Model 15950, Germany). Enzymatic hydrolysis method as described by King and Armstrong (1934) was used to determine the alkaline phosphatase (ALP) activity.

\subsection{Histopathological analyses}

At the end of the 96-h exposure period, survivors were euthanized with $40 \%$ ethyl alcohol (FAFIOYE, FAGADE and ADEBISI, 2005). The liver was harvested, fixed in $10 \%$ neutral buffered formalin prior to paraffin embedding, sectioning at $5 \mu \mathrm{m}$ and staining with haematoxylin and eosin (ROBERTS, 1978; BANCROFT and COOK, 1994) for histopathological examinations under light microscopy.

The degree of tissue change (DTC) method as described by (POLEKSIC and MITROVIC-TUTUNDZIC, 1994) was modified and used to determine the nature and severity of lesions in the sampled liver. Lesions in the liver were progressively classified in stages of tissue damage, respectively where the sum of the number of lesion types within each of the three stages multiplied by the stage coefficient gives numerical values of the DTC using the formula: DTC $=\left(1 \times \sum I\right)+\left(10 \times \sum I I\right)+$ $\left(100 \times \sum I I I\right)$. Lesions that did not alter the normal functioning of the liver were classified as Stage $I$ lesions. Lesions that were more severe and impaired the normal functioning of the liver were classified as Stage II lesions. Lesions that were very severe and induced irreparable liver damage were classified as Stage III lesions. The results were graded and interpreted as follows: $0-10$ (normal liver tissue); $11-20$ (slightly damaged liver); 21 - 50 (moderately damaged liver); 50 - 100 (severely damaged liver); >100 (irreversibly damaged liver).

\subsection{Statistical analyses}

Data were expressed as mean $( \pm$ SEM) and subjected to ANOVA and Tukey's multiple comparison test for statistical significance at $\mathrm{p}<0.05$ using GraphPad software programme (GraphPad Prism, version 4.0, San Diego, California, USA.). The DTC between exposed groups and the unexposed control group were compared for statistical significance $(\mathrm{p}<0.05)$ using the same GraphPad software programme.

\section{Results}

The exposed fish showed various signs of toxicity ranging from uncoordinated movements, repeated attempts to jump out of reconstituted extracts and excessive mucous secretions to increased opercula movements, exposed snouts, adoption of different postures and sudden darts. Mortality was recorded in some of the exposed fish (Table 1) resulting in the establishment of an $\mathrm{LC}_{50}$ value of $7.15 \mathrm{mgL}^{-1}$ for ethanol extract of $A$. obesum stem bark in the exposed C.gariepinus over the 96-h period. Mortality was significantly $(\mathrm{p}<0.05)$ concentration-dependent.

Changes in serum liver enzymes in the exposed fish are presented in Table 2. There were increased AST and ALT activities with decreased ALP activity in C. gariepinus exposed to ethanol extract of $A$. obesum stem bark but these changes were non-significant $(\mathrm{p}>0.05)$ with increasing extract concentration. Histopathological changes in the liver of $C$. gariepinus exposed to ethanol extract of $A$. obesum stem bark are as shown in Figure 1-6. There were vacuolations and cellular infiltration (Stage $I$ lesions) with congestion and haemorrhage (Stage II lesions) and necrosis of the hepatocytes (Stage III 


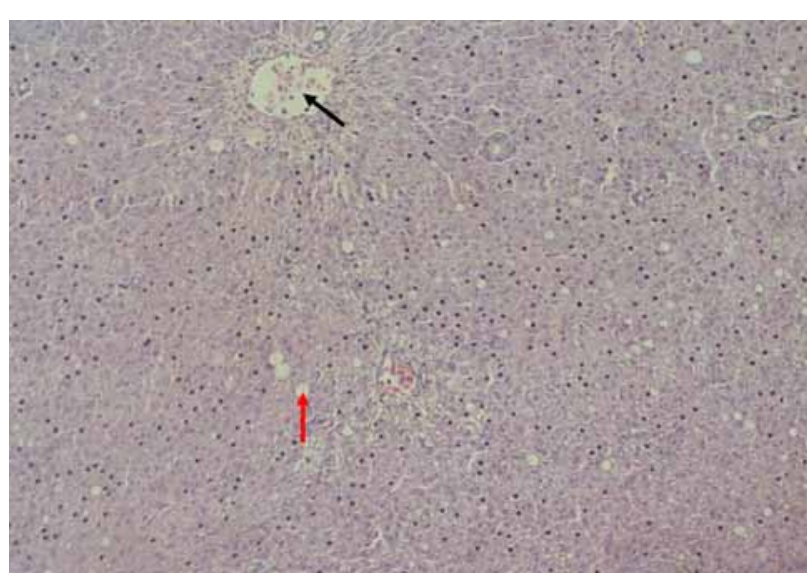

Figure 1. Photomicrograph of the liver of the unexposed control Clarias gariepinus. Note the central vein (black arrow) with hepatocyte vacuolations (red arrow). H \& E x 64.

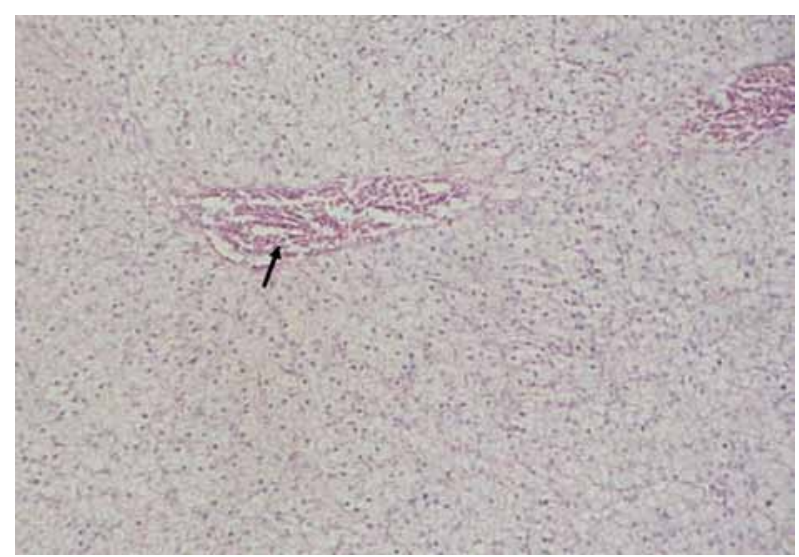

Figure 2. Photomicrograph of the liver of Clarias gariepinus exposed to $6.25 \mathrm{mgL}^{-1}$ of ethanol extract of Adenium obesum stem bark. Note congestion of the central vein (black arrow). H \& E x 64 .

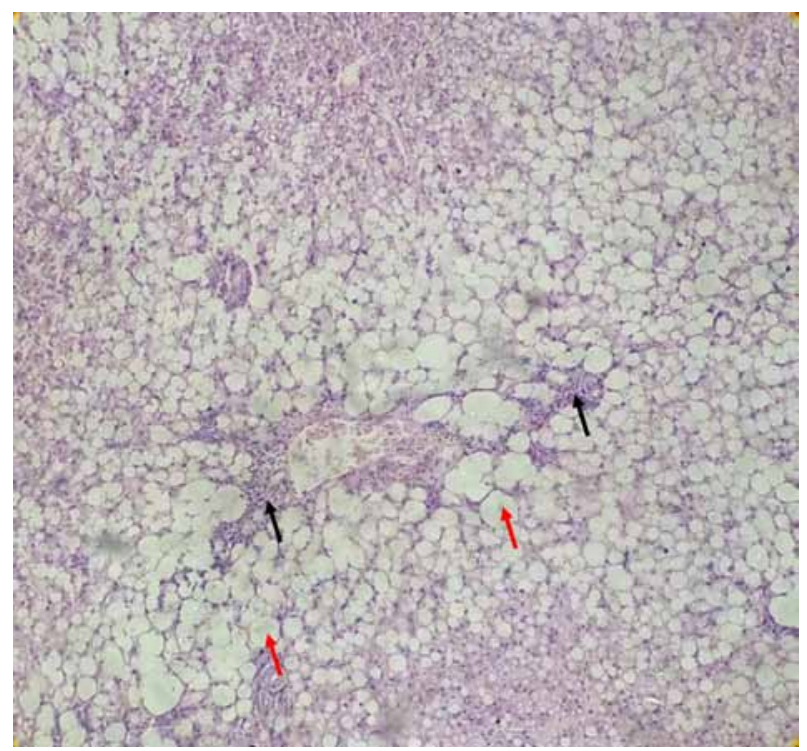

Figure 3. Photomicrograph of the liver of Clarias gariepinus exposed to $7.50 \mathrm{mgL}^{-1}$ of ethanol extract of Adenium obesum stem bark. Note mononuclear cellular infiltration (black arrows) and vacuolation of the hepatocyte (red arrows) within the liver acinus. H \& E x 64.

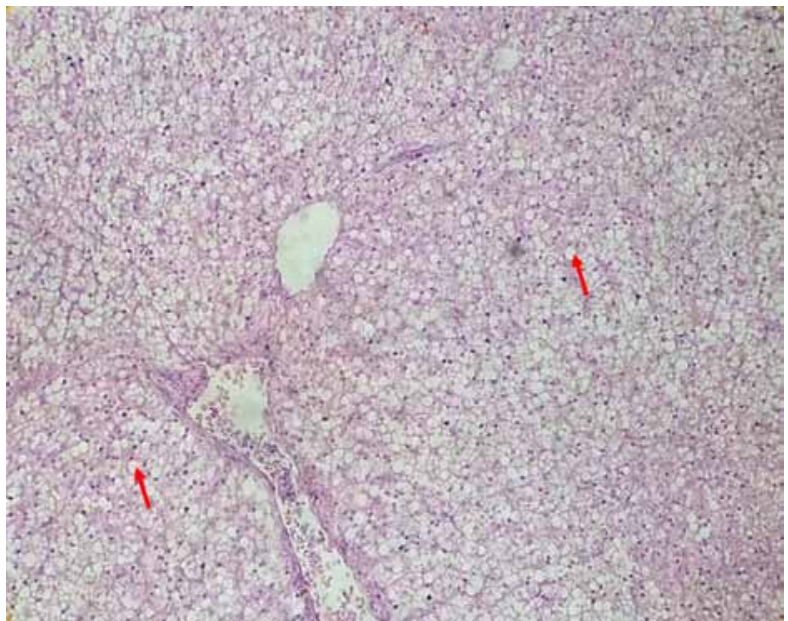

Figure 4. Photomicrograph of the liver of Clarias gariepinus exposed to $8.20 \mathrm{mgL}^{-1}$ of ethanol extract of Adenium obesum stem bark. Note vacuolation of the hepatocyte (red arrows). H \& E x 64 .

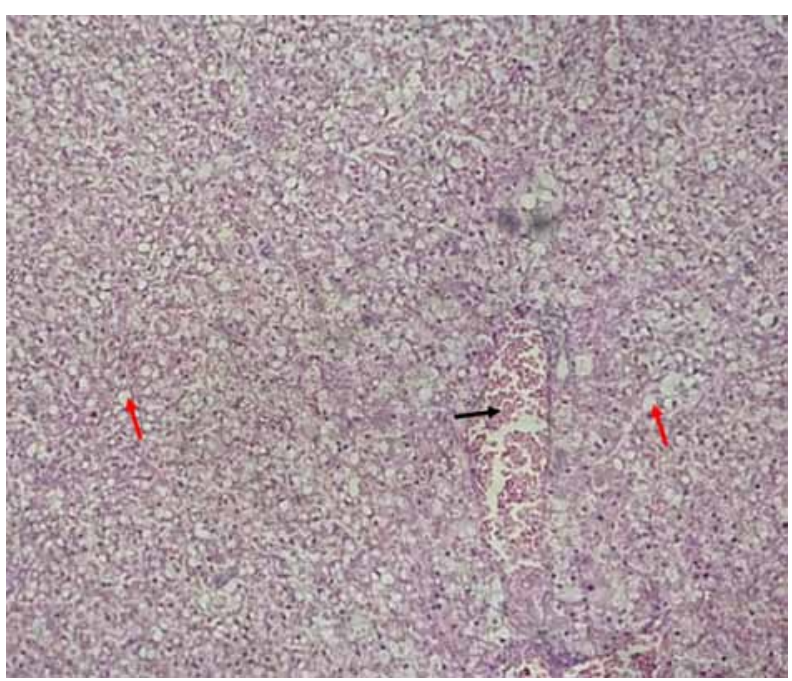

Figure 5. Photomicrograph of the liver of Clarias gariepinus exposed to $8.80 \mathrm{mgL}^{-1}$ of ethanol extract of Adenium obesum stem bark. Note congestion of the central vein (black arrow) and vacuolation of the hepatocyte (red arrows) with loss of liver architecture. H \& E x 64.

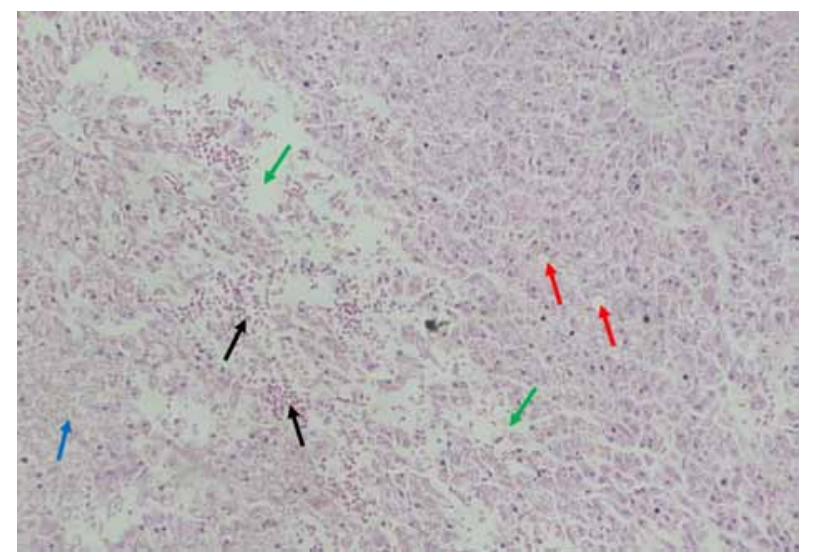

Figure 6. Photomicrograph of the liver of Clarias gariepinus exposed to $9.30 \mathrm{mgL}^{-1}$ of ethanol extract of Adenium obesum stem bark. Note hepatocyte necrosis (green arrows) with degenerated hepatocytes (blue arrow), hepatocyte vacuolations (red arrows) and haemorrhage (black arrows) within the centrolubular area of the liver. H \& E x 64. 
Table 1. Mortality in Clarias gariepinus exposed to ethanol extract of Adenium obesum stem bark over the 96-h exposure period.

\begin{tabular}{|c|c|c|c|c|c|c|c|}
\hline \multirow{2}{*}{$\begin{array}{c}\text { Extract } \\
\text { Concentration } \\
(\mathrm{mgL}-1)\end{array}$} & \multirow{2}{*}{$\begin{array}{l}\text { No. of } \\
\text { fish }\end{array}$} & \multicolumn{4}{|c|}{ Mortality ( \pm SEM) per exposure period (h) } & \multirow[b]{2}{*}{ Mortality } & \multirow{2}{*}{$\begin{array}{c}\text { Percent } \\
\text { mortality (\%) }\end{array}$} \\
\hline & & 24-h & $48-h$ & $72-h$ & $96-h$ & & \\
\hline 9.30 & 7 & 0.33 & 4.67 & 1.00 & 0.00 & $6.00^{*}$ & 85.71 \\
\hline 8.80 & 7 & $( \pm 0.33)$ & $( \pm 1.20)$ & $( \pm 1.00)$ & $( \pm 0.00)$ & $5.33^{*}$ & 76.14 \\
\hline 8.20 & 7 & 0.33 & 5.00 & 0.00 & 0.00 & $5.00 *$ & 71.43 \\
\hline 7.50 & 7 & $( \pm 0.33)$ & $( \pm 1.00)$ & $( \pm 0.00)$ & $( \pm 0.00)$ & 3.33 & 47.57 \\
\hline 6.25 & 7 & 1.00 & 3.33 & 0.67 & 0.00 & 1.00 & 14.28 \\
\hline 0.00 & 7 & $( \pm 0.57)$ & $( \pm 0.33)$ & $( \pm 0.67)$ & $( \pm 0.00)$ & 0.00 & 0.00 \\
\hline \multirow[t]{6}{*}{ (Control) } & & 0.00 & 3.33 & 0.00 & 0.00 & & \\
\hline & & $( \pm 0.00)$ & $( \pm 0.33)$ & $( \pm 0.00)$ & $( \pm 0.00)$ & & \\
\hline & & 0.00 & 0.33 & 0.67 & 0.00 & & \\
\hline & & $( \pm 0.00)$ & $( \pm 0.33)$ & $( \pm 0.33)$ & $( \pm 0.00)$ & & \\
\hline & & 0.00 & 0.00 & 0.00 & 0.00 & & \\
\hline & & $( \pm 0.00)$ & $( \pm 0.00)$ & $( \pm 0.00)$ & $( \pm 0.00)$ & & \\
\hline
\end{tabular}

*Statistically significant $(\mathrm{p}<0.05)$ compared to the control.

Table 2. Serum liver enzymes of Clarias gariepinus exposed to ethanol extract of Adenium obesum stem bark over the 96-h period.

\begin{tabular}{|c|c|c|c|c|c|c|}
\hline \multirow[b]{2}{*}{$\begin{array}{l}\text { Serum biochemical } \\
\text { parameters }\end{array}$} & \multicolumn{6}{|c|}{ Extract concentration } \\
\hline & $\begin{array}{c}0.00 \\
(\text { Control }) \\
\end{array}$ & $\begin{array}{c}6.25 \\
\left(\mathrm{mgL}^{-1}\right)\end{array}$ & $\begin{array}{c}7.50 \\
\left(\mathrm{mgL}^{-1}\right)\end{array}$ & $\begin{array}{c}8.20 \\
\left(\mathrm{mgL}^{-1}\right)\end{array}$ & $\begin{array}{c}8.80 \\
\left(\mathrm{mgL}^{-1}\right)\end{array}$ & $\begin{array}{c}9.30 \\
\left(\mathrm{mgL}^{-1}\right)\end{array}$ \\
\hline $\mathrm{AST}^{*}(\mathrm{UL}-\mathrm{l})$ & 95.00 & 120.70 & 117.00 & 120.70 & 111.70 & 127.00 \\
\hline ALT (UL-1) & $( \pm 10.41)$ & $( \pm 6.57)$ & $( \pm 2.65)$ & $( \pm 8.840$ & $( \pm 3.76)$ & $( \pm 3.00)$ \\
\hline \multirow[t]{4}{*}{ ALP(UL-1) } & 39.14 & 45.83 & 41.00 & 46.80 & 42.20 & 44.33 \\
\hline & $( \pm 2.54)$ & $( \pm 2.77)$ & $( \pm 1.98)$ & $( \pm 5.31)$ & $( \pm 4.52)$ & $( \pm 5.36)$ \\
\hline & 23.14 & 21.57 & 21.00 & 19.80 & 19.20 & 21.00 \\
\hline & $( \pm 1.35)$ & $( \pm 1.33)$ & $( \pm 0.93)$ & $( \pm 0.74)$ & $( \pm 1.20)$ & $( \pm 1.73)$ \\
\hline
\end{tabular}

*AST - aspartate aminotransferase activity. ALT - alanine aminotransferase activity; ALP - alkaline phosphatase activity.

Table 3. Degree of tissue change in the liver of Clarias gariepinus exposed to ethanol extract of Adenium obesum stem bark over the $96-\mathrm{h}$ period.

\begin{tabular}{ccccccc}
\hline Tissue & \multicolumn{5}{c}{ Degree of tissue change per extract concentration } \\
& 0.00 & 6.25 & 7.50 & 8.20 & 8.80 & 9.30 \\
Liver & $($ Control $)$ & $\left(\mathrm{mgL}^{-1}\right)$ & $\left(\mathrm{mgL}^{-1}\right)$ & $\left(\mathrm{mgL}^{-1}\right)$ & $\left(\mathrm{mgL}^{-1}\right)$ & $\left(\mathrm{mgL}^{-1}\right)$ \\
& 0.67 & 14.20 & 12.43 & 12.67 & 55.40 & 119.33 \\
* Statistically significant $(\mathrm{p}<0.05)$ & $( \pm 2.38)$ & $( \pm 1.43)$ & $( \pm 1.67)$ & $( \pm 28.92)^{*}$ & $( \pm 3.07)^{*}$ \\
\hline
\end{tabular}

lesions). Although histopathological lesions were observed in the exposed and unexposed fish, those in the unexposed control groups were to a lesser extent. However, the severity but not the type of the observed lesions in the exposed fish was concentration-dependent. There was moderate damage to the liver of C. gariepinus exposed to ethanol extract of A. obesum stem bark based on the cumulative DTC value of $42.31 \pm 9.23$. There were significant $(\mathrm{p}<0.05)$ differences between the DTC of the exposed and the unexposed control group as shown in Table 3 .

\section{Discussion}

The observed repeated attempts to jump out of reconstituted extracts with excessive mucous secretion were adaptation behavioural responses to escape from the toxic aquatic environment in addition to trying to coat body surfaces so as to limit the absorption of the toxicant (ABALAKA and AUTA, 2010). The increased opercula movements with continuous snout exposure could be due to respiratory distress while the adoption of different postures with sudden darts might be due to nervous compromise (ABALAKA and AUTA, 2010). Similar signs of toxicity were reported in C.gariepinus exposed to Caraca papaya and Nicotiana tobaccum (AYOTUNDE, OFFEM and BEKEH, 2011; KORI-SIAKPERE and OVIROH, 2011 ). This is in addition to hyperactivity and uncoordinated movements observed in ticks exposed to aqueous extract of A. obesum stem back (MGBOJIKWE, 2000). The presence of obvious signs of toxicity, including mortality in some of the exposed fish affirmed the global use of $A$. obesum to kill fish (ADAMU, ABAYEH, AGHO et al., 2005; OYEN, 2008). Although changes observed in AST, ALT and ALP activities of the exposed fish were non-significant $(\mathrm{p}>0.05)$, the extract did cause some forms of liver damage. This is because these serum enzymes are sensitive indicator of even minor cellular damage (PALANIVELU, VIJAYAVEL, BALASUBRAMANIAN et al., 2005 ) where ALT is more hepato-specific compared to AST activity (HERFINDAL and GOURLEY, 2000).

Fish liver is one of the organs that is most affected by toxicants in the water (RODRIQUES and FANTA, 1998) 
due to the fact that it is the organ that is most associated with detoxification and biotransformation process because of its function, position and blood supply (VAN der OOST, BEYER and VERMEULEN, 2003) hence the lesions that usually observed in their liver (ROCHA and MONTEIRO, 1999). The observed congestion and haemorrhage were vascular responses to the toxicity of the extract in the exposed fish. Increased vacuolations of the hepatocytes could be indicative of fatty change, which are pathological responses in toxic exposures (HINTON and LAUREN 1990; PACHECO and SANTOS, 2002; WOLF and WOLFE, 2005). Although feed withdrawal (starvation) prior to and during the 96 -h exposure period could have contributed to the vacuolations in the liver of the exposed fish, the fact that these changes were more pronounced in the liver of the exposed fish compared to those of the control fish showed that it might be due to metabolic disturbances resulting from the toxic exposure. The observed liver fatty change might be due to either excessive mobilisation of fat to the liver thereby exceeding its capacity to metabolise it or liver damage such that it cannot adequately metabolise the fat (MOHAN and MOHAN, 2011). However, such steatosis is usually reversible except in some extreme cases, resulting in disturbed functional efficiency of the affected liver (COTRAN, KUMAR and COLLINS, 1999; MOHAN and MOHAN, 2011). Tissue hypoxia caused by gill epithelia damage in the exposed fish could have caused the observed hepatic lesions (COUCH, 1975; MOHAMMED, 2001).

\section{Conclusion}

The ethanol extract of $A$. obesum stem bark was toxic to the exposed C.gariepinus with evidence of histopathological hepatotoxicity and therefore, can be used as an effective organic piscicide to eradicate fish from aquatic environments in order to help safeguard native species and/or the stocked desired fish species.

Acknowledgements: This is to recognise the contributions of $\mathrm{Mr} \mathrm{S}$. M. Meslam and Mr Abdulsalam umar to the work.

\section{Disclosure}

The work was privately funded and therefore, the authors declare no conflict of interests or make no financial disclosure.

\section{References}

ABALAKA, SE. and AUTA, J. Toxicity of aqueous and ethanol extracts of Parkia biglobosa pods on Clarias gariepinus juveniles. Journal of Animal and Veterinary Advances, 2010., vol. 9, n. 6, p. 1068-1072. http://dx.doi.org/10.3923/javaa.2010.1068.1072.

ABU-DAHAB, R. and AFIFI, F. Anti-proliferative activity of selected medical plants of Jordan against a breast adenocarcinoma cell line (MCF7). Scientia Pharmaceutica, 2007., vol. 75, n. 3, p. 121-136. http://dx.doi.org/10.3797/scipharm.2007.75.121.

ADAMU, HM., ABAYEH, OJ., AGHO, MO., ABDULLAHI, AL., UBA, A., DUKKU, HU. and WUFEM, BM. An ethnobotanical survey of Bauchi State herbal plants and their antimicrobial activity. Journal of Ethnopharmacology, 2005, May 13., vol. 99, n. 1, p. 1-4. http://dx.doi.org/10.1016/j.jep.2004.12.025. PMid:15848012.

ARBONNIER, M. Trees, shrubs and lianas of west african dry zones. S.1.: MNHN, CIRAD, MARGRAF, 2004. 161 p.
AYOTUNDE, EO., OFFEM, BO. and BEKEH, AF. Toxicity of Caraca papaya Linn: Haematological and piscicidal effect on adult catfish (Clarias gariepinus). Journal of Fisheries and Aquatic Sciences, 2011., vol. 6, n. 3, p. 291-308. http://dx.doi.org/10.3923/ jfas.2011.291.308.

BADWEN-DAVIS, J. The Adenium species. 2010. Available from: http://www.ehow.com/about_6721472_adenium-species.html. Access in: $21 / 12 / 2010$.

BANCROFT, JD. and COOK, HC. Manual of histological techniques and their diagnostic application. London: Churchill Livingstone, 1994. p. 289-305.

BRUTON, MN. On the size reached by Clarias gariepinus. Journal of Limnology Society of South Africa, 1976., vol. 2, p. 57-58.

BRUTON, MN. The life history styles of invasive fishes in Southern Africa. In MACDONALD, IAW., KRUGER, FT. and FERRAR, AA. (editors). The ecology and management of biological invasions in Southern Africa. Capetown: Oxford University Press, 1986. p. 201-208.

CAGAUAN, AG. and ARCE, RG. Overview of pesticides use in rice-fish farming in South East Asia. In DELA CRUZ, CR., LIGHTFOOD, C., COASTA PIERCE, B., CARANGAL, VR, BIMBAO, MP. (editors). Rice-Fish Research Development in Asia. Manila: ICLARM, 1992. p. 217-33. Conference Proceeding, no. 24.

CAGAUAN, AG., GALAITES, MC. and FAJARDO, LJ. Evaluation of botanical piscicides on Nile Tilapia (Oreochromis niloticus L.) and mosquito fish (Gambusia affinis Baird and Girard). In Proceedings of the Sixth International Symposium on Tilapia in Aquaculture, Manila, 2004. p. 179-187.

CASAL, CMV. Global documentation of fish introductions: the growing crisis and recommendations for action. Biological Invasions, 2006, vol. 8, n. 1, p. 3-11. http://dx.doi.org/10.1007/s10530-005-0231-3.

COTRAN, RS., KUMAR, V. and COLLINS, T. Cellular pathology II: adaptations, intracellular accumulations and cell aging. In COTRAN, RS., KUMAR, V. and COLLINS, T. (editors). Robbins's pathological basis of diseases. 6th ed. Philadelphia: W. B. Saunders Company, 1999. $39 \mathrm{p}$.

$\mathrm{COUCH}, \mathrm{JA}$. Histopathological effects of pesticides and related chemicals in the livers of fishes. In RIBELIN, WE. and MIGAKI, G. (editors). The pathology of fishes. Madison: University of Wisconsin Press, 1975. p. 559-584.

FAFIOYE, OO. Lethal and sub-lethal effect of extracts of Parkia biglobosa and Rahpia vinifera on some fresh water fauna. Ibadan: University of Ibadan, 2001. 216 p. [PhD Dissertation].

FAFIOYE, OO. Plants with piscicidal activities in South Western Nigeria. Turkish Journal of Fisheries and Aquatic Sciences, 2005., vol. 5, p. 91-97.

FAFIOYE, OO., FAGADE, SO. and ADEBISI, AA. Toxicity of Raphia vinifera, P. beauv fruit extracts on biochemical composition of Nile Tilapia (Oreochromis niloticus, Trewavas). Biokemistri, 2005, vol. 17, n. 2, p. 137-142.

FINNEY, DJ. Probit Analysis. London: Cambridge University Press; 1971.p. 123-125

Food and Agriculture Organization of the United Nations - FAO. Cultured Aquatic Species Information Programme: Clarias gariepinus (Burchell, 1822). Food and Agriculture Organization of the United Nations for a world without hunger. 2011. Available from: http:// www.fao.org/fishery/culturedspecies/clarias_gariepinus/en. Access in $08 / 08 / 2011$.

Food and Agriculture Organization of the United Nations - FAO. Manual on African Magur (Clarias gariepinus) Culture in Bangladesh. FAO, 1992. Available from: http://www.fao.org/docrep/field/003/ AC379E00.htm. Access in 14/10/2007. 
GRIBGRATOK, S. The role of cyanide on the fisheries. Thai Fisheries Gazette, 1981, vol. 34, p. 499-506.

HASTUTI, D., SURANTO, and SETYONO, P. Variation of morphology, karyotype and protein band pattern of Adenium (Adenium obesum) varieties. Nusantara Bioscience, 2009, vol. 1, n. 2, p. 78-83.

HERFINDAL, DR. and GOURLEY, ET. Textbook of Therapeutic Drug and Disease Management. 7th ed. Philadelphia: Lippincott Williams and Wilkins, 2000. $83 \mathrm{p}$.

HETCH, T., OELLERMAN, L. and VERHEUST, L. Perspectives and clariid catfish culture in Africa. In LEGENDRE, M. and PROTEAU, JP. (editors). The biology and culture of catfishes. Paris: Aquatic Living Resources, 1996. p. 197-206. Hors Series, vol. 9.

HINTON, DE. and LAUREN, DJ. Liver structural alterations accompanying chronic toxicity in fishes: potential biomarkers of exposures. In McCARTHY, JF. and SHUGART, LR. (editors). Biomakers of Environmental Contamination. Boca Raton: Lewis publishers, 1990. p. 17-52.

KING, EJ. and ARMSTRONG, AR. A convenient method for determining serum and bile phosphatase activity. Canadian Medical Association Journal, 1934, October., vol. 31, n. 4, p. 376-381. PMid:20319659.

KOESOMADINATA, S. Pesticide as a major constraint in integrated agriculture-aquaculture farming system. In PULLIN, RSV. and SHEHADEH, ZH. (editors). Integrated Agriculture-Aquaculture Farming System. Manila: ICLARM, 1980. p. 45-51. Conference Proceeding, no. 4.

KORI-SIAKPERE, O. AKE, JEG. and IDOGE, E. Haematological characteristics of the African Snakehead, Parachanna obscura. African Journal of Biotechnology, 2005, vol. 4, n. 6, p. 527-530.

KORI-SIAKPERE, O. and OVIROH, EO. Acute toxicity of tobacco (Nicotiana tobaccum) leaf dust on the African catfish: Clarias gariepinus (Burchell, 1822). Archives of Applied Science Research, 2011, vol. 3 , n. 2, p. 1-7.

KULAKKATTOLICKAL, AT. and KRAMER, DL. The role of air breathing in the resistance of bimodally respiring fish to waterborne toxins. Journal of Fish Biology, 1988, vol. 32, n. 1, p. 119-127. http://dx.doi.org/10.1111/j.1095-8649.1988.tb05340.x.

LINTERMANS, M. Recolonization by the mountain galaxias Galaxias didus of a mountain stream after the eradication of rainbow trout Oncorbynchus mykiss. Marine \& Freshwater Research, 2000, vol. 51, n. 8, p. 799-804. http://dx.doi.org/10.1071/MF00019.

MARKING, LL. Evaluation of toxicants for the control of carp and other nuisance fishes. Fisheries, 1992, vol. 17, n. 6, p. 6-13. http:// dx.doi.org/10.1577/1548-8446(1992)017<0006:EOTFTC>2.0.CO;2.

MGBOJIKWE, LO. Acaricidal properties of the aqueous stem bark extract of Adenium obesum. Jos: University of Jos, 2000 [PhD Dissertation].

MOHAMMED, FA. Impacts of environmental pollution in the southern region of Lake Manzalah, Egypt on the histological structures of the liver and intestine of Oreochromis niloticus and Tilapia zillii. Journal of Egyptian Academic Society for Environmental Development, 2001, vol. 2, p. 25-42.

MOHAN, H. and MOHAN, S. Essential pathology for dental students. 4th ed. New Delhi: Jaypee Brothers Medical Publishers, 2011. p. 48-50.

MONDAL, D., BARAT, S. and MUKHOPADHYAY, MK. Toxicity of neem pesticides on a fresh water loach, Lepidocephalichthys guntea (Hamilton Buchanan) of Darjeeling district in West Bengal. Journal of Environmental Biology, 2007, vol. 28, n. 1, p. 119 122. PMid:17717997.

MURPHY, BR. and WILLIS, DR. Sampling with toxicants. In: MURPHY, BR. and WILLIS, DR. (editors). Fisheries techniques. 2nd ed. Bethseda: American Fisheries Society, 1996. p. 303-333.
OLUFAYO, MO. Haematological characteristics of Clarias gariepinus (Burchell 1822) juveniles exposed to Derris elliptica roots powder. African Journal of Food and Agriculture, Nutrition and Development, 2009 , vol. 9, p. 920-933.

OMINO, EA. and KOKWARO, JO. Ethnobotany of Apocynaceae species in Kenya. Journal of Ethnopharmacology, 1993, vol. 40, n. 3, p. 167-180. http://dx.doi.org/10.1016/0378-8741(93)90065-D. PMid:8145572.

Organization for Economic Co-operation and Development - OECD. Guidelines for the Testing of Chemicals No. 203: fish acute toxicity test. Paris: OECD, 1992. p. 1-9.

OYEN, LPA. Adenium obesum (Forssk.) Roem. \& Schult. In SCHMELZER, GH. and GURIB-FAKIM, A. (editors). Plant Resources of Tropical Africa 11 (1): medicinal plant 1. Wageningen: PROTA/ Backhuys/CTA, 2008. p. 46-49.

PACHECO, M. and SANTOS, MA. Biotransformation, genotoxic, and histopathological effects of environmental contaminants in European eel (Anguilla anguilla L.). Ecotoxicology and Environmental Safety, 2002, vol. 53, n. 3, p. 331-347. http://dx.doi.org/10.1016/S01476513(02)00017-9. PMid:12485576.

PALANIVELU, V., VIJAYAVEL, K., BALASUBRAMANIAN, SE. and BALASUBRAMANIAN, MP. Influence of insecticidal derivative (cartap hydrochloride) from the marine polycheate on certain enzyme systems of the fresh water fish Oreochromis mossambicus. Journal of Environmental Biology, 2005, vol. 26, n. 2, p. 191-195. PMid:16161972.

PICKER, M. and GRIFFITHS, C. Alien and invasive animals: a South African perspective. Cape Town: Struik Publishers, 2001.

PLAIZIER AC. A Revision of Adenium Roem and Schult. and of Diplorhynchus Welw. ex Fic. \& Hiern (Apocynaceae). Wageningen: Mededelingen Landbouwhogeschool Publication, no. 80-12, 1980. p. 1-40.

POLEKSIC, V. and MITROVIC-TUTUNDZIC, V. Fish gills as a monitor of sublethal and chronic effects of pollution. In MULLE, R. and LLYOD, R. (editors). Sublethal and Chronic Effects of Pollutants on Freshwater Fish. London: Fishing News Books, 1994. p. 339-352.

ROBERTS, RJ. The patho-physiology and systemic pathology of teleost. In ROBERTS, RJ. (editor). Fish Pathology. London: Bailliére Tindall, 1978. p. 55-91

ROCHA, E. and MONTEIRO, RAE. Histology and cytology of fish liver: a review. In SAKSENA, DN. (editor). Ichthyology: recent research advances. Enfield: Science Publishers, 1999. p. 321-344.

RODRIQUES, EL. and FANTA, E. Liver histopathology of the fish Brachydanio rerio after acute exposure to sublethal levels of the organophosphate Dimetoato 500. Revista Brasileira de Zoologia, 1998, vol. 15, p. 441-450. http://dx.doi.org/10.1590/S010181751998000200014 .

SCHWARTZ, MK., CEDIEL, N., CURNOW, DH., FRASER, CG., PORTER, CJ., WORTH, HG. and ZINDER, O. International Federation of Clinical Chemistry, Education Committee and International Union of Pure and Applied Chemistry, Division of Clinical Chemistry: definition of the terms certification, licensure and accreditation in clinical chemistry. Journal of Clinical Chemistry and Clinical Biochemistry, 1985, vol. 23, n. 12, p. 899-901. PMid:3831231.

SILVA, SS., NGUYEN, TT., TURCHINI, GM., AMARASINGHE, US. and ABERY, NW. Alien species in aquaculture and biodiversity: a paradox in food production. Ambio, 2009, vol. 38, n. 1, p. 24-28. http://dx.doi.org/10.1579/0044-7447-38.1.24. PMid:19260343.

SINGH, A., SINGH, DK., MISRA, TN. and AGARWAL, RA. Molluscicides of plant origin. Biological Agriculture and Horticulture, 1996., vol. 13, n. 3, p. 205-225. http://dx.doi.org/10.1080/014 48765.1996 .9754782 . 
SMITH, CJ., SHAW, BJ. and HANDY, RD. Toxicity of single walled carbon nanotubes to rainbow trout, (Oncorhynchus mykiss): respiratory toxicity, organ pathologies, and other physiological effects. Aquatic Toxicology (Amsterdam, Netherlands), 2007, vol. 82, n. 2, p. 94-109. http://dx.doi.org/10.1016/j.aquatox.2007.02.003. PMid:17343929.

STALIN SI., KIRUBA, S. and DAS, SSM. A comparative study in the toxicity of a synthetic pyrethroid Deltamethrin and a neem based pesticide Azadirachtin to Poecilia reticulate Peters 1859 (Cyprinodontiformes: Poeciliidae). Turkish Journal of Fisheries and Aquatic Science, 2008., vol. 8, p. 1-5.

TERAZAKI, M., THARNBUPPA, P. and NAKAYAMA, Y. Eradication of predatory fishes in shrimp farms by utilization of Thai tea seed. Aquaculture, 1980, vol. 19, n. 3, p. 235-242. http://dx.doi. org/10.1016/0044-8486(80)90047-2.

VAN ANDEL, T. The diverse use of fish poison plants in northwest Guyana. Economic Botany, 2000., vol. 54, n. 4, p. 500-512. http:// dx.doi.org/10.1007/BF02866548.
VAN DER OOST, R., BEYER, J. and VERMEULEN, NP. Fish bioaccumulation and biomarkers in environmental risk assessment: a review. Environmental Toxicology and Pharmacology, 2003, vol. 13, n. 2, p. 57-149. http://dx.doi.org/10.1016/S13826689(02)00126-6. PMid:21782649.

WOLF, JC. and WOLFE, MJ. A brief overview of nonneoplastic hepatic toxicity in fish. Toxicologic Pathology, 2005, vol. 33, n. 1, p. 75-85. http://dx.doi.org/10.1080/01926230590890187. PMid:15805058.

ZORLONI, A. Evaluation of plants used for the control of animal ectoparasitosis in southern Ethopia (Oromiya and Somali regions). Pretoria: University of Pretoria, 2000. [Degree of Magister Scientiae].

Received: April 2, 2014

Accepted: July 9, 2015 